\title{
Electoral Competition and Legislative Minority Parties: Schlesinger's Parties in a Legislative Setting
}

\author{
Thomas H. Little, University of Texas at Arlington
}

According to Joseph A. Schlesinger, modern American political parties are driven by the desire to win office, and policy objectives are secondary. The purpose of this paper is to examine the nature of minority legislative parties in the context of Schlesinger's market- based definition of political parties. The objective of this paper is to determine if institutional competition has similar consequences for legislative parties as individual competition has for individual candidates. Analysis of the senate minority parties in Maryland, North Carolina, Delaware, Virginia and Ohio reveals that institutional interparty competition and the probability of gaining majority status have a dramatic effect on the nature, influence, organization and cohesion of minority parties. Noncompetitive minorities tend to give little emphasis to the external and campaign responsibilities of the party organization, are not penalized for their minority status, are poorly organized and tend not to vote along party lines. On the other hand, competitive minorities give great attention to the elections, are highly organized and vote in a cohesive manner. Ironically, increased corporate party organization and activity are accompanied by decreased individual influence and success for members of the minority party.

The legislative minority political party is a critical component of the American political process. Members of minority parties comprise over forty percent of the state legislatures, and over forty-five percent of the United States Congress (House and Senate). Members of minority parties propose legislation, debate policy matters and help determine matters of public policy significance. The minority party is alive and well in the American political system.

Yet, relative to the myriad studies of the majority legislative party at the national (Huitt 1961; Ripley 1969; Sinclair 1983; Palazzolo 1992) and state (Jewell 1962; Barber 1966) level, the loyal opposition has received very limited scholarly attention. With the exception of Jones (1970) and Connelly and Pitney (1994), who discuss the significance and complexities of the minority party in Congress, and Harmel (1986), who examines the partisanship of minority parties in five "one party predominant" states, we are presented with a narrow picture of legislative minorities. One is led to believe that minority parties are ineffective (Connelly and Pitney 1988), unorganized (Jewell 1992) and of generally little consequence. The purpose of this paper is to begin to fill the void in our understanding of legislative

Thomas H. Little is Assistant Professor of Political Science, University of Texas at Arlington.

The American Review of Politics, Vol. 16, Fall, 1995: 299-316

(1995 The American Review of Politics 
minority parties and re-evaluate the image of these parties through the lens of Schlesinger's "theory of party organization."

In accordance with Schlesinger's description of political parties as "market-based organizations," it is argued that the nature of partisan politics and the place of the minority party in the legislative system are a function of the competitive nature of the particular institution in which they exist (Schlesinger $1985,1154-58) .{ }^{1}$ The intent of this article is to show that minority parties are not identical, but rather that they may be cooperative or obstructionist, simple or complex, aggressive or passive, influential or impotent, depending upon the nature of the competitive environment within which they exist.

\section{Schlesinger's Theory of Party Organizations Applied to Legislative Minority Parties}

While Schlesinger theorizes about political parties in the broad political setting, his definition of parties as organizations designed "to gain control of government in the name of the group [party] by winning election to public office" $(1985,1153)$ is quite applicable to legislative parties in general and legislative minority parties in particular. Schlesinger's focus on electoral success and the market is reflected in two realities of legislative parties. First, in the legislature, as in any democratic institution, it is necessary to win an election before one can be concerned with governing. The centrality of electoral politics is the underlying premise of Schlesinger's approach. Second, an individual legislator's success within the institution (and quite possibly his or her own re-election) is dependent on the number of other partisans elected. While every member seeks election in a discrete and separate constituency, each is cognizant that the electoral success of one member increases the potential legislative success of other members of the party. Given this acknowledgement of a corporate interest, individual partisans should assist in the election of his or her colleagues, creating the sense of "team" that is characteristic of Schlesinger's definition of parties (1984, 386). Legislative parties, with their individual and corporate interests in gaining the votes necessary to govern, fit well the Schlesinger definition of political parties.

Further, Schlesinger's concept of market-based parties is of particular significance for the minority party. As a result of the power associated with majority status in the legislative setting, the minority party is likely to pay particular attention to the electoral goal outlined by Schlesinger (Jewell $1992,27)$. The minority party can hope to have sustained influence only by competing effectively in the electoral market place and winning the 
opportunity to govern. Schlesinger's market-based definition of political parties has three implications that, at least in part, determine the objectives, influence and behavior of minority parties in competitive settings (1984, 381-384).

First, this definition establishes the objective for the minority party. Electoral success, or market success, is necessary for the continued participation in the policy arena. This is particularly true of the minority party. While the majority party is burdened with the responsibility of governing, the minority party may direct virtually all of its attention to the electoral objective (Jones 1970, 22; Patterson 1990). Theoretically, the minority party should be noticeably partisan in its actions and focus on public and electorally-oriented activities that will bring exposure and an increased share of the market (voters). Studies of the parties in Congress (Herrnson 1988; Little and Patterson 1993), and the New York Assembly (Stonecash 1988) reveal minority parties that do indeed focus significant attention on the goal of getting their members elected, distributing resources in terms of winnability rather than ideology, in accordance with the electoral objectives expressed by Schlesinger.

Second, the market orientation affects the distribution of influence within the institution. Those who are most successful at achieving the electoral objective (gaining a majority of the voter market) will have greater influence within the political system as well (Schlesinger 1984, 384). While governing may be merely a by-product of the electoral objective, it can contribute to the achievement of that objective. According to democratic theory, those that govern successfully will be rewarded with re-election. Therefore, one would expect the majority party to use its position to prohibit the minority party from gaining the legislative successes that might contribute to electoral successes (Moore and Thomas 1991; Meyer 1980). This is particularly likely when that minority party is an electoral threat to majority status.

Finally, the market approach implies the production of a tangible good. While Schlesinger (1984) notes that the identification of collective benefits is somewhat problematic in terms of political parties in general, it is much more concrete for legislative parties. The collective benefit is partisan legislative success which can be defined by legislative cohesion and unity. Assuming that legislative success will result in electoral success, or at least not detract from it, one would expect legislators to have an inclination to support the party. Further, in exchange for such support, leaders may offer incentives which personalize the reward and increase the chance of that member's re-election (Little 1995). The party leaders may, for example, ensure that the members successfully pass those bills that are important to the electoral constituency. Again, this collective goal is perhaps even more 
important for the members of the minority party than for their majority colleagues. In a setting where institutional power of the minority is limited, the only hope for institutional success is the power of unity of the minority (Jones 1970).

\section{The Importance of Interparty Competition In the Legislature}

While Schlesinger's theory revolves around the significance of competition for individual offices, he acknowledges the importance of collective or corporate competition in determining the level of activity of the parties (1985, 1154-55). The significance of institutional competition cannot be overestimated in determining variations in the activities of different minority parties (Jewell 1962; Gierzynski 1992, 78; Jewell 1992, 27). No party has the resources to be successful, or even competitive, in campaigns for all offices. Centers of electoral party activists (nuclei) "will emerge in those constituencies where the party has some short- or long-run chance of winning the office" (Schlesinger 1985, 1154). While at least skeletal minority party organizations are likely to exist in all legislatures, they will be of electoral significance only in those institutions offering a realistic opportunity for gaining majority status.

Institutional competition affects not only the level of effort expended on elections and the degree of attention paid to the electorate, but also the success and behavior of individual legislators. Where party competition is great, we can expect a great gulf between the success of majority and minority members. This is because legislative success may lead to electoral success and that is a risk the majority party should be unwilling to take. However, it is likely that such a gulf will disappear in institutions where competition is lower. ${ }^{2}$ Further, in a competitive institution both parties will be well organized and strive to achieve cohesiveness. In less competitive institutions, neither party will make serious attempts to enforce cohesiveness. In other words, parties will work the hardest and be the most partisan when the chances of victory and political rewards are the highest.

In summary, Schlesinger's theory offers several suggestions regarding the attitudes, influence and behavior of the legislative minority party in relation to its institutional partisan context. The following three hypotheses will be examined below:

H1: The attention of the legislative minority party to external and electoral matters, as well as the propensity to aggressively challenge incumbents of the other party is positively related to the level of interparty competition within that institution. 
H2: The individual-level advantage of majority status is inversely related to the level of institutional competition.

H3: Levels of party corporate organization and cohesiveness are positively related to the level of interparty competition.

\section{Senates in Five States}

In order to test the implications of Schlesinger's theory on legislative minority parties in different electoral environments, the minority parties in five institutions of relatively similar structure and size, but various levels of partisan competition, will be examined. We will look at the senate minority parties of Maryland, North Carolina, Delaware, Virginia and Ohio. Key characteristics of these five institutions are offered in Table 1. As one can see, there is considerable variation in the size of the majority in each of these institutions, as well as the electoral trend and the seat changes necessary to alter the majority status.

Without question, the Republican party of Maryland is the weakest of the five minority parties in the study. Republicans held only seven of the 47 seats in the Senate and about the same proportion of the House (16 of 141) during the session under examination (1989). Further, during the previous ten years, they had gained or lost no more than one seat, with caucus membership ranging from six to eight seats. ${ }^{4}$ Prospects of defeating majority candidates seem quite low and the possibility of majority status unimaginable. The Republican minority in North Carolina in 1989 appeared to be on the rise. It grew from one member in 1978 to 13 in 1989, comprising over a quarter of the membership. ${ }^{5}$ Furthermore, it was bolstered by the electoral success of the first Republican governor to be re-elected in the state.

\section{Table 1. Characteristics of the Minority Party by State}

\begin{tabular}{lrclc}
\hline State & $\begin{array}{c}\text { Minor. \#/ } \\
\text { Chamber \# }\end{array}$ & $\begin{array}{c}\text { Minority } \% \\
\text { of Total }\end{array}$ & $\begin{array}{c}\text { Election } \\
\text { Trend* }\end{array}$ & $\begin{array}{c}\text { Swing } \\
\text { Margin** }\end{array}$ \\
\hline Maryland & $7 / 47$ & $14.8 \%$ & No Change & 17 \\
North Carolina & $13 / 50$ & $26.0 \%$ & Gained 3 & 13 \\
Delaware & $6 / 21$ & $28.6 \%$ & Lost 2 & 5 \\
Virginia & $18 / 40$ & $45.0 \%$ & Gained 8 & 2 \\
Ohio & $14 / 33$ & $43.0 \%$ & Lost 1 & 3
\end{tabular}

*Election trend represents change from the previous election for the minority party.

**Represents the number of seats the minority party must gain to loss its minority status. 
However, the party was still twelve seats away from majority status and had fewer seats than immediately following the 1972 elections. The Delaware General Assembly presents somewhat of a paradox. While control of the House has vacillated between Republican and Democratic control with Republicans currently in firm control, the smaller senate has remained in the hands of the Democrats for two decades with Republicans currently controlling six of the 21 seats ( $28 \%$ ). Further, the Republicans lost two seats in the election of 1990. I would argue that the Delaware Republican party is more competitive than the North Carolina Senate Republicans for two reasons. First, Delaware does not have the century long history of one party domination apparent in North Carolina and second, while there are only six Republicans, a shift of only five seats would give them a majority. Results of the 1994 election reduced that "magic number" to two (9 Republican seats to 12 for the Democrats).

The Senate of Virginia may well serve as a window into the future for many Southern legislatures. In 1989, the Republicans held only a quarter of the 40 positions in the Senate. However, following the elections of 1991 , they were a minority by only four seats, controlling 18 seats. Further, 11 of their 18 members were freshmen, many having beaten senior Democrats. Virginia Republicans were a strong minority, with clear designs on majority status. A gain of only two seats in 1995 could deny the Democrats the majority status they have held since reconstruction. However, it is not yet clear if the Republican gains are an indication of a legitimate two-party system, or a response to a slow economy or disillusionment with Democratic Governor Douglas Wilder. Given this question in Virginia, the most competitive of the states is clearly Ohio. Both parties held the majority in the 1980s and the minority Democrats vividly remember the power associated with it. With only 33 members, a swing of three seats would put the Democrats back in control. While the necessary seat swing to majority status is less in Virginia, Ohio Democrats are deemed more competitive because they have proven their ability to win majority status and have vivid recollection of the power of majority status. ${ }^{6}$

\section{Measuring Party Activities, Success and Cohesion}

In order to test the hypotheses outlined above, data were gathered from several sources in each of the states. Two measures were used to determine the degree of attention that the minority parties placed on external and electoral activities, one based on the nature of expected leadership behavior and the second on actual behavior. First, leaders and members of the minority party were queried ${ }^{7}$ as to the appropriate activities for their legislative 
leaders, those members elected to direct and represent the party. The responses were coded as internal, external campaign oriented and external noncampaign oriented. ${ }^{8}$ Given the importance of membership expectations in determining leadership activities (Sinclair 1990; Little 1995), this measure will allow us to determine the degree of influence that the party as an organization places on electoral and external activities. Second, a look at the degree and nature of partisan campaign activities offers a more direct measure of the campaign emphasis of the party. Campaign activities are examined in terms of the amount of money distributed and the informal "rules" of distribution.

Second, in order to test the proposition that competition affects the distribution of legislative influence, an analysis of legislative success was conducted. Legislative success at the individual level is measured as the proportion of bills sponsored or cosponsored by an individual which received a majority of votes for final passage. This measure is similar to that used by Matthews $(1960,278)$ to determine success in Congress, and referred to later by Frantzich (1979) as the legislator's "batting average." Matthews argues that the measure, although simplistic, was a "fair index of his overall effectiveness in the Senate" $(1960,278) .{ }^{9}$ The party success rate is the average rate of passage for all members of the party. ${ }^{10}$

Finally, the proposition concerning growing party activity and unity is addressed in two ways. First, information concerning the complexity of the party organization, gathered during personal interviews with members, is presented. Second, party unity scores involving contested votes are examined for the five parties to determine if competition does indeed lead to greater unity and cohesion as indicated by Schlesinger. Data for all of these measures were gathered from the personal interviews described above, campaign financial reports, legislative journals and legislative voting records.

\section{The Findings: Testing the Hypotheses}

\section{Competition Breeds a Competitive Attitude}

The first clear implication of Schlesinger's theory is that minority parties with a realistic hope of gaining majority status will place the greatest emphasis on external activities associated with electoral gains. The information presented in Figure 1 strongly supports this claim. Members from the weakest minority parties, in Maryland and North Carolina, are the least likely to define party activities in terms of external and campaign activities. External activities, including interaction with the media, the governor, the 
Figure 1. Party Leadership Focus: Attention to Campaigns and External Activities

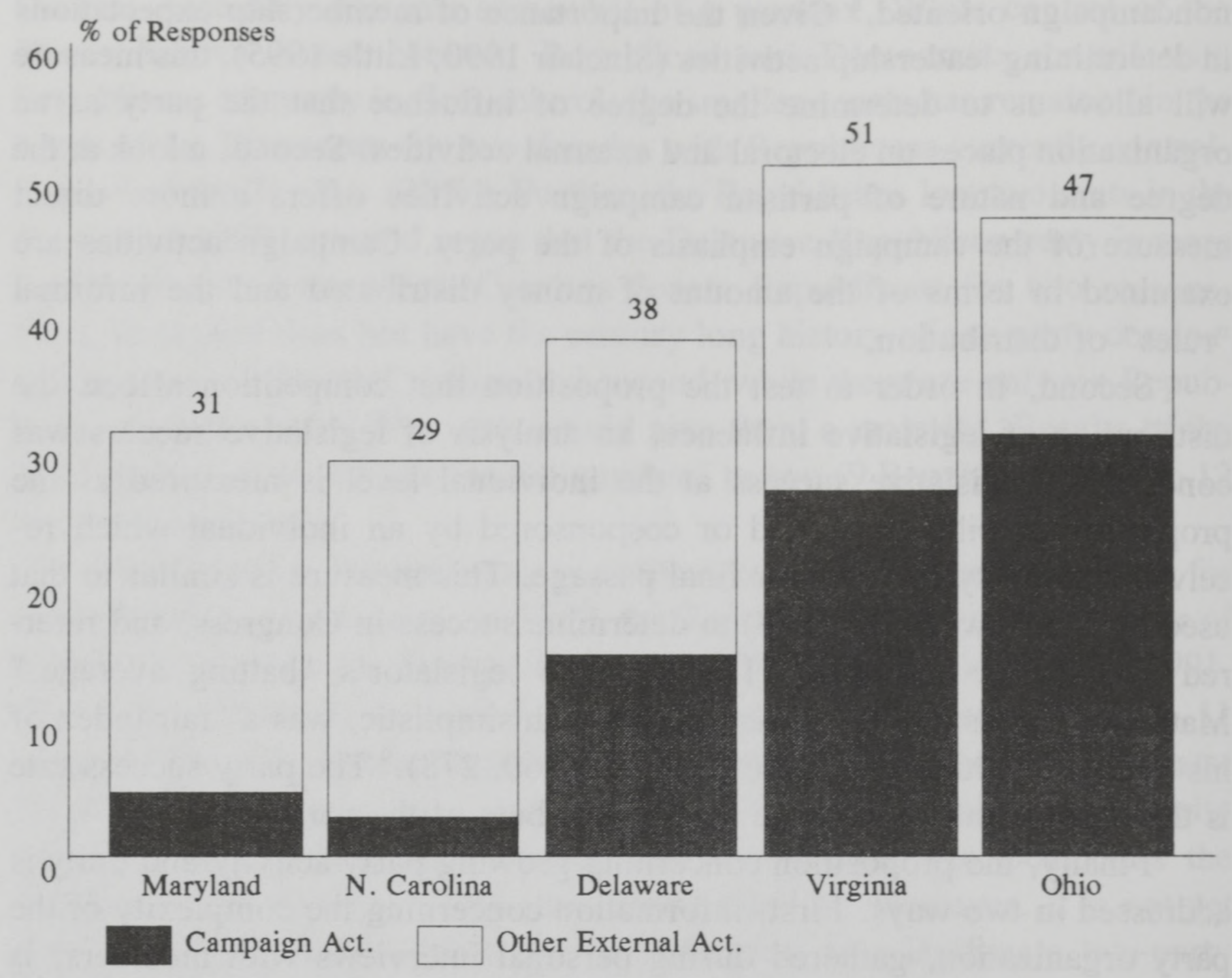

Source: Based on interviews with members

speaker, the general public, and campaign activities comprise less than a third of the party activities in these two "one party predominant" states. More significantly, campaign related activities comprise less than five percent of the anticipated party activities reported by minority members. These parties are in the minority and expect the party organization to do little to change that status.

As the parties move toward parity, there is a noticeable shift in the direction of expectations related to external activities in general and campaign activities in particular. About forty percent of the responses associated with minority leadership in Delaware relate to external activities and over a third of those external activities are campaign related. In addition to coordinating party activities and working with the majority, the leaders of the minority party in Delaware are expected to be cognizant of the coming elections. In Virginia, where the minority has shown the greatest gains in recent years, members look to the party organization to continue 
that trend, with over half of the responses concerning external activities. Further, over a quarter of those responses concerned campaign assistance, including money, services, recruitment and training. Finally, as one would expect, the most campaign intensive minority party is the Ohio Democrats, where three of every ten responses were directly related to campaign assistance. In Ohio, the Senate parties are primarily a means for assisting in electoral activities, with all four leaders in the minority party expected to raise money and see that the party's candidates succeed.

According to Figure 1, party leaders in competitive states are expected to speak on behalf of the party and work in campaigns. Table 2 addresses the actual campaign behavior of the parties. In a competitive state, one would expect the party to raise a great deal of money, distribute much of it to challengers who are at a financial disadvantage (Jacobson 1987; Gierzynski 1992), and target those seats considered most vulnerable. Table 2 reveals that the party leaders are trying to meet the expectations outlined in Figure 1. While the minority parties in all five states raised and distributed money during the election cycle prior to data collection, the amounts collected and methods of distribution are quite different. The Maryland House-Senate Republican Caucus distributed $\$ 38,000$ to Senate candidates in the 1986-1990 election cycle. While most of the expenditures did go to either challengers or those seeking an open seat, the data reveal a limited willingness to contribute to challengers (32\% to challengers) and perhaps anger incumbent Democrats, focusing instead on the few open seats (52\% to open seats). However, there is some evidence of targeting, with over a third $(38 \%)$ of the money going to close races. The limitations of this targeting effort are indicated by the fact that two competitive challengers received no money and safe incumbents did receive assistance.

\section{Table 2. Extent and Nature of Campaign Activities in Minority Parties}

\begin{tabular}{lrrrrrr}
\hline State & $\begin{array}{c}\text { Total } \\
\text { Expended* }\end{array}$ & $\begin{array}{c}\% \text { to Chal./ } \\
\% \text { to Open }\end{array}$ & $\begin{array}{r}\% \text { to Comp. } \\
\text { Races** }\end{array}$ & $\begin{array}{c}\text { Largest } \\
\text { Contribut. }\end{array}$ & $\begin{array}{r}\text { Average } \\
\text { Winner }\end{array}$ \\
\hline Maryland & $\$$ & 38,000 & $32 \% / 53 \%$ & $38 \%$ & $\$ 6,000$ & $\$ 94,946$ \\
North Carolina & 8,000 & $20 \% / 10 \%$ & $0 \%$ & 800 & 20,164 \\
Delaware & 2,500 & $40 \% / 0 \%$ & $60 \%$ & 450 & 12,602 \\
Virginia & 99,400 & $71 \% / 29 \%$ & $87 \%$ & 15,400 & 81,510 \\
Ohio & $2,035,284$ & $78 \% / 18 \%$ & $52 \%$ & 377,545 & 118,898 \\
*Total given in contributions or in-kind services to candidates of the party. & \\
** Competitive races are defined as those elections in which the winner receives less than 55\% of \\
the votes cast in the general election.
\end{tabular}


North Carolina Senate Republicans present a clear picture of an electorally inactive minority party. All North Carolina incumbents received $\$ 800.00$ during the 1986-1988 election cycle. The relatively insignificant contributions were distributed evenly among the incumbents and a few challengers. No assistance went to candidates in the 13 competitive races. While party leaders in Delaware raised and distributed a limited amount of money, the lower cost of victory in that state makes the money, though limited, more valuable. They made some effort to target vulnerable seats, with 60 percent of the money going to competitive races. Further, the party leaders gave to challengers $(40 \%)$ as well as incumbents $(60 \%)$.

Finally, the two most competitive minority parties, Virginia Republicans and Ohio Democrats, were extremely active. In addition to providing seminars and recruiting candidates, both parties contributed substantial amounts of money and services. Interviews with leaders reveal a conscious effort to target competitive races, which is supported by the data in Table 2. Over 80 percent of the money distributed by Virginia Republicans went to competitive races. Further, Virginia leaders indicated a willingness to challenge incumbent Democrats ( $71 \%$ of the money went to challenge incumbent Democrats), as evidenced by the distribution of resources. In fact, they gave no money to incumbent members and the caucus showed a great willingness to challenge incumbent Democrats. Likewise, only four percent of the money distributed by Ohio Democrats went to incumbents. The deciding factor for distribution in these two states was, as expected, winnability and need, not incumbency. Also, over half of the money distributed here went to competitive seats, although less than a quarter of all races were competitive. Given the high cost of victory in Virginia $(\$ 81,510)$ and Ohio $(\$ 118,898)$, it is not surprising that these parties spent a great deal of money. In attitude and action, minority parties in competitive states make a calculated and well funded effort directed toward achieving majority status, while their counterparts in less competitive positions (with the noted exception of some targeting efforts in Maryland) make a token effort, at best.

\section{To the Victor Go the Spoils}

Schlesinger argues that the persons within a party that have electoral victories will possess influence. The logic applies to the corporate party as well, with the winners (majority party members) expected to have greater influence. This should be particularly true in parties where the minority party is large enough to be considered an electoral threat. Table 3 reveals the strong influence of interparty competition on partisan legislative success. 


\section{Table 3. Party Status and Legislative Success}

\begin{tabular}{lccccc}
\hline State & $\begin{array}{c}\text { Majority } \\
\text { Success }\end{array}$ & $\begin{array}{c}\text { Minority } \\
\text { Success }\end{array}$ & $\begin{array}{c}\text { Majority } \\
\text { Advantage }\end{array}$ & $\begin{array}{c}\text { Avg. Maj. } \\
\text { Bills Int. }\end{array}$ & $\begin{array}{c}\text { Avg. Min } \\
\text { Bills Int. }\end{array}$ \\
\hline Maryland & .60 & .71 & -.11 & 33.13 & 27.14 \\
North Carolina & $.57 * *$ & $.64 * *$ & -.07 & 78.73 & 50.77 \\
Delaware & .69 & .61 & .08 & 62.20 & 44.17 \\
Virginia & .75 & .66 & .09 & 48.14 & 48.56 \\
Ohio & .38 & .08 & .30 & 26.58 & 31.93
\end{tabular}

*Legislative Success is measured as a proportion of bills sponsored or co-sponsored by a legislator that passed the Senate.

**Appropriations Bills are excluded in North Carolina because of the difficulty of determining their inclusion in the budget.

In Maryland and North Carolina, majority status appears to be a hinderance rather than a help when it comes to legislative success. Members of the minority party, who introduce or cosponsor substantially fewer bills than their majority colleagues, have a higher passage rate than their colleagues across the aisle. Seventy-one percent of the bills sponsored or co-sponsored by Republicans received a majority of the votes on the floor, while the Democratic average was only 60 percent. Likewise, North Carolina Republicans were successful an average of 64 percent of the time, while majority Democrats averaged a passage rate of seven percent less. However, in more competitive environments, majority status becomes an advantage rather than a burden. A bill with the name of a Democrat in Delaware or Virginia at its top was just under 10 percent ( 8 and $9 \%$, respectively) more likely to pass than one sponsored or cosponsored by a Republican. Finally, the most lopsided advantage came in the highly competitive Ohio Senate. While the average Ohio Republican could expect about 40 percent of the bills with his or her name on them to pass, an Ohio Democrat was lucky if one in ten of his or her bills passed. In fact, the most successful Democrat (21\%) was about half as successful as the average Republican (38\%). As predicted, as interparty competition increases, so does the importance of partisanship in determining legislative success. In competitive institutions, to the victor clearly go the spoils.

\section{Organized and Cohesive Parties}

The third implication of Schlesinger's definition of political parties concerns the organization and behavior of the parties within the institution. It is argued that parties in competitive situations will organize themselves in 
a manner that will enable the party to attain collective goods and help individual members achieve personal objectives (Schlesinger 1985, 1154-55). The result of this increased organization should be a stronger party presence as reflected in increased party voting.

The data presented in Table 4 represent the nature of the formal legislative party organization as described by members of the party. It is quite clear that the party organizations are more complex in states with competitive parties. The Maryland Republican Caucus, which meets as a caucus only once each session (to elect its leader), elects a floor leader who appoints a whip. In conjunction with the House floor leader, the Minority Leader oversees the distribution of limited campaign funds. The party has no formal staff. In a similar manner, North Carolina Republican senators elect three leaders, one of whom oversees the distribution of a small chest of funds to candidates. The party caucus has no staff and meets irregularly, generally to gather information from members of the Republican administration, rather than to develop policy positions. The six member Delaware Republican Caucus elects only a floor leader who then selects a whip.

\section{Table 4. The Organizational Structure of Five Minority Parties}

\begin{tabular}{|c|c|c|c|c|c|c|}
\hline State & $\begin{array}{l}\text { \# Caucus } \\
\text { Members }\end{array}$ & $\begin{array}{l}\text { Elected } \\
\text { Leaders }\end{array}$ & $\begin{array}{l}\text { App'ted } \\
\text { Leaders }\end{array}$ & $\begin{array}{c}\text { Paid } \\
\text { Leaders** }\end{array}$ & $\begin{array}{c}\text { Campaign } \\
\text { PACs }\end{array}$ & $\begin{array}{c}\text { Minority } \\
\text { Staff }\end{array}$ \\
\hline Maryland & 7 & 1 & 1 & 0 & $\begin{array}{l}\text { House/ } \\
\text { Senate }\end{array}$ & $\begin{array}{l}0 \text { Profess. } \\
0 \text { Clerical }\end{array}$ \\
\hline North Carolina & 13 & 3 & 0 & 1 & $\begin{array}{l}\text { House/ } \\
\text { Senate }\end{array}$ & $\begin{array}{l}0 \text { Profess. } \\
0 \text { Clerical }\end{array}$ \\
\hline Delaware & 6 & 1 & $1 *$ & 2 & $\begin{array}{l}\text { House/ } \\
\text { Senate }\end{array}$ & $\begin{array}{l}2 \text { Profess. } \\
1 \text { Clerical }\end{array}$ \\
\hline Virginia & 18 & 3 & 2 & 0 & $\begin{array}{l}\text { House/ } \\
\text { Senate }\end{array}$ & $\begin{array}{l}3 \text { Profess. } \\
2 \text { Clerical }\end{array}$ \\
\hline Ohio & 14 & 1 & $3 *$ & 4 & Senate & $\begin{array}{l}8 \text { Profess. } \\
3 \text { Clerical }\end{array}$ \\
\hline
\end{tabular}

*While leaders in Ohio and Delaware are formally elected, they run as a slate selected by the minority leader designate.

**The additional salary for the leadership positions in the five institutions are as follows:

Maryland

North Carolina

Delaware

Virginia

Ohio
No additional compensation.

Minority Leader-\$2,316/year.

Minority Leader-\$7,000/year; Minority Whip- $\$ 4,500 /$ year.

No additional compensation.

Minority Leader-\$14,737/year; Assistant Minority Leader-\$10,418/year; Minority Whip-\$6,100/year; Assistant Minority Whip-\$1,611/year. 
However, the minority leader does have the benefit of a small caucus staff (one full time, one session intern, and one clerical) that assists in the development of policy positions. During the legislative session, the party members meet two or three times a week to prepare for the session on a given day.

Virginia Republicans have the most intricate organization, electing a floor leader, caucus chair and policy committee chair, in addition to the two whips who are appointed by the floor leader. Over a quarter ( 5 of 18) of the Senate Republican caucus members hold a formal leadership position. Further, in addition to caucus meetings prior to the daily session, the leader meets with freshmen following each session to explain proceedings and answer policy questions. While the policy committee and floor leaders are responsible for policy development and party unity, the caucus chair and the two member caucus staff are responsible for the recruitment, education and funding of candidates. Finally, the Ohio Democrats elect a slate of four leaders to run the caucus, with each responsible for the collection and distribution of campaign money, as well as uniting the party. The caucus meets regularly before each day's session and may meet two or three times each day as events warrant (Jewell 1992 supports this assessment). The primary responsibility of the caucus staff is the re-election of incumbent Democrats and the defeat of incumbent Republicans.

Interestingly, there appears to be no relationship between the number of leadership positions and the salary associated with leadership responsibilities. Table 4 indicates that the two most complex organizations differ greatly in compensation. Virginia Republican leaders receive no financial benefits from their service, while all four Ohio Democrats had a financial incentive to serve. As suggested by Schlesinger, parties in more competitive situations are more inclined to build a complex organization that will allow them to govern as well as win elections. ${ }^{11}$ Further, it is only as the party becomes competitive that the senate party is organized as an independent and significant "nucleus" with its own campaign arm rather than merely an arm of the bicameral "legislative party."

While Schlesinger's approach implies that personal goals comprise the primary objectives of modern political parties, he notes that members of parties in competitive situations should be most likely to work together to produce collective goods. Interparty electoral competition is likely to breed intraparty policy cooperation $(1985,1155)$. Table 5 supports this proposition. While the average Maryland Republican supported the party just over 60 percent of the time when there was a party split, the average Ohio Democrat supported the party on over 90 percent of such votes. ${ }^{12}$ Further, just over a third of all competitive votes in Maryland were of a partisan 
Table 5. Partisan Voting and Party Unity

\begin{tabular}{|c|c|c|c|c|}
\hline State & $\begin{array}{l}\text { \# of Competi- } \\
\text { tive Votes* }\end{array}$ & $\begin{array}{c}\#(\%) \text { of } \\
\text { Partisan Votes** }\end{array}$ & $\begin{array}{l}\text { Avg. Support on } \\
\text { Partisan Votes }\end{array}$ & $\begin{array}{l}\text { Std. Dev. of } \\
\text { Party Support }\end{array}$ \\
\hline Maryland & 180 & $69(38.3 \%)$ & $62.1 \%$ & $20.1 \%$ \\
\hline North Carolina & 272 & $130(47.8 \%)$ & $78.6 \%$ & $7.2 \%$ \\
\hline Delaware & 132 & $68(51.5 \%)$ & $73.5 \%$ & $10.1 \%$ \\
\hline Virginia & 224 & $107(47.8 \%)$ & $73.3 \%$ & $7.0 \%$ \\
\hline Ohio & 70 & $48(68.6 \%)$ & $92.7 \%$ & $2.2 \%$ \\
\hline
\end{tabular}

nature, while more than two-thirds could be defined as such in Ohio. About half of the competitive votes in North Carolina, Delaware and Virginia were partisan in nature, but minority members stuck together on about 75 percent of those votes.

The standard deviation measures reveal that not only do minority members in competitive institutions tend to have higher average party loyalty, but they are less likely to have outliers that skew the average scores in one direction or the other. Their unity is a reflection of common vote patterns across the caucus rather than a few members that are very loyal. With the exception of the Delaware Republicans, the deviation in party voting decreases as competition increases. The average Ohio Democrat varied from the 92.7 percent score by just over two percent, while the seven Maryland Republicans varied by over 20 percent in their limited support. As competition increases, legislative parties do act more like governing parties as Schlesinger predicts.

\section{Conclusion}

In presenting his market-based theory of political parties, Joseph A. Schlesinger defines competition primarily in terms of individual elections. Parties focus their attention on individual elections that are significant and winnable. This theory is particularly pertinent for minority parties because electoral success is a precondition for policy success. This study indicates that the attitudes, success, organization and behavior of minority political parties are not only a function of individual electoral environments, but are also responsive to the corporate electoral environment of the party. 
While one might expect minority legislative parties to focus all attention on the external and campaign activities that will bring electoral gains, parties in the state of "permanent minority status" have limited interest in such affairs. Their attention is directed toward matters within the institution and apart from the election. Even when attention is given to campaigns, it is more of an incumbent protection fund than an effort to elect new members. On the other hand, minority parties in competitive institutions have a great deal of interest in the matters of elections and the activities beyond the confines of the institution. Competitive minorities are more interested in gaining the seats necessary for majority status, as Schlesinger would suggest, than in governing.

Just as minority parties are expected to have limited responsibility for governing, one expects them to have limited success at it. Once again, institutional competition has a great effect on this relationship. Minority party legislators in one-party institutions are, in fact, more successful than their colleagues in the majority. However, minority members in competitive institutions have much lower legislative success, despite their growing numbers. As the numerical advantage of the majority party shrinks, its hold over power and influence seems to strengthen.

Finally, while minority parties are often considered ineffective and unorganized, intraparty competition has a dramatic effect on this dimension as well. As Schlesinger's theory would suggest, minority parties grow in organization and cohesion as a result of competition. The minority legislative parties in one party states elect nominal leaders, give token campaign contributions to incumbents and split their vote almost as often as they vote together. Minority parties in competitive situations, on the other hand, develop an intricate organization, actively develop candidates, campaigns and policy positions, and vote together a majority of the time. Only in competitive institutions do political parties act like political parties in the traditional sense.

The implications of these findings are significant for those who study politics as well as casual observers. First, it is impossible to understand any political phenomenon without understanding the context in which it exists. We can only fully understand the nature of political parties and legislative parties if we understand the situation from which they draw their shape, power and influence. Second, we should not merely ignore minority parties in the legislature or elsewhere assuming they are inconsequential. Indeed, they might be quite important in their ability to either influence policy directly (in less competitive institutions) or force the majority to take particular positions to defend its majority status (in competitive institutions). As parties in the state legislatures become more competitive, scholars, 
politicians and casual observers should be aware of the consequences on the politics and policies of the institution.

\section{NOTES}

The author gratefully acknowledges the assistance of Mary McGovney and Lawrence L. Schack in gathering and coding data utilized in this research and The School of Public Affairs of the American University in helping to finance travel and the purchase of journals necessary to complete the research.

${ }^{1}$ The level of interparty competition as a predictor of legislative behavior and organization is well documented by other scholars as well (Jewell 1955; Jewell 1962; Hamm and Hedlund 1994).

${ }^{2}$ While studies indicate that the success and activity of legislative parties will become more partisan as interparty competition increases (Little and Patterson 1993), there is little evidence that they will automatically lose that partisan desire as they lose those seats.

${ }^{3}$ While one might define the electoral strength of a legislative party in terms of the percentage of the vote received in each individual race, I will rely on the more traditional measure based on the proportion of seats held, as well as some indication of the electoral trend.

${ }^{4}$ The 1994 Republican landslide resulted in an unprecedented 15 Republican members. However, even following such a "landslide," they make up less than a third of the membership.

${ }^{5}$ Recent elections support the proposition that Republicans were on the rise. The 1994 election saw them move within a single seat of majority status (26-24).

${ }^{6}$ Also, Ohio is in a region where strong partisanship is more the norm than the traditionally one-party Virginia. This would also support the placement of Ohio as more competitive.

${ }^{7}$ Efforts were made to interview all minority party members. Open format interviews were conducted with all minority members in Maryland (7), North Carolina (13), and Delaware (6). Interviews were completed with all but two minority members in Ohio (13) and all but five in Virginia (13). As part of a general survey on legislative leadership and legislative life, respondents were asked to describe the appropriate activities for each of the elected and appointed party leaders and to suggest any improvements.

${ }^{8}$ Internal activities include those that contribute primarily to the performance of partisan or institutional activities within the legislative body. Noncampaign external activities relate to those activities targeted at external actors (i.e., the governor, the speaker), but not primarily electoral in nature. Campaign activities are defined as those activities most directly related to the legislative campaigns, such as raising and distributing money, providing polling, speaking on behalf of the membership and monitoring institutional campaign staff. These activities are explored more thoroughly in Little (1995).

'The proportion of bills passed with the member as primary sponsor was rejected as a measure because of the number of members that were the primary sponsor of no legislation. 
${ }^{10}$ Obviously, the use of floor passage rates as a measure of legislative effectiveness is problematic and ignores other aspects of the legislative process, such as constituency work and committee work. The importance of these activities is not disputed. It simply is not the focus of this study. Further, this "batting average" is widely used and is most comparable across institutions. Given the comparative nature of this research, it was deemed the most feasible and appropriate measure.

${ }^{11}$ While there is some correlation between the number of members in the minority caucus and the total number of leaders, the monotonic increase in staff support as competition increases supports the importance of competition as a driving force.

${ }^{12}$ Competitive votes are defined as those in which at least 10 percent of the members voted in the minority. The party success rate is the proportion of times that the average member supported the party on competitive votes.

\section{REFERENCES}

Barber, James D. 1966. Leadership Strategies for Legislative Party Cohesion. Journal of Politics 28:347-367.

Connelly, William F. Jr., and John J. Pitney. 1994. Congress' Permanent Minority: Republicans in the U.S. House. Lanham, Maryland: Rowman and Littlefield.

Frantzich, Stephen. 1979. Who Makes our Laws: The Legislative Effectiveness of Members of the U.S. Congress. Legislative Studies Quarterly 4:409-428.

Gierzynski, Anthony. 1992. Legislative Party Campaign Committees in the American States. Lexington, Kentucky: University of Kentucky Press.

Harmel, Robert. 1986. Minority Partisanship in One-Party Predominant Legislatures: A Five State Study. Journal of Politics 48:728-740.

Hedlund, Ronald D., and Keith Hamm. 1994. Party Control of State Legislative Committees in the Twentieth Century. Paper presented at the annual meeting of the Western Political Science Association.

Herrnson, Paul S. 1988. National Decisionmaking, Strategies and Resource Distribution in Congressional Elections. Western Political Quarterly 42:301-323.

Huitt, Ralph K. 1961. Democratic Party Leadership in the Senate. American Political Science Review 55:333-344.

Jacobson, Gary C. 1987. The Politics of Congressional Elections, 2nd ed. Boston: Little, Brown.

Jewell, Malcolm E. 1962. The State Legislature: Politics and Practice. New York: Random House.

1992. The Partisan Role of State Legislative Leaders. Paper presented at the annual meeting of the American Political Science Association, Chicago, September 3-6.

Jones, Charles O. 1970. The Minority Party in Congress. Boston: Little, Brown.

Little, Thomas H. 1995. Understanding Legislative Leadership Beyond the Chamber: The Members' Perspective. Legislative Studies Quarterly 20:269-289.

Little, Thomas H., and Samuel C. Patterson. 1993. The Organizational Life of Congressional Parties. The American Review of Politics 14:39-70.

Matthews, Donald R. 1960. U.S. Senators and Their World. New York: Random House. 
Meyer, Katherine. 1980. Legislative Influence: Toward Theory Development Through Causal Analysis. Legislative Studies Quarterly 5:563-585.

Moore, Michael K., and Sue Thomas. 1991. Explaining Legislative Success in the U.S. Senate: The Role of the Majority and Minority Parties. Western Political Quarterly 44:959-970.

Palazzolo, Daniel J. 1992. The Speaker and the Budget: Leadership in the Post-Reform House of Representatives. Pittsburgh: University of Pittsburgh Press.

Patterson, Samuel C. 1990. Party Leadership in the U.S. Senate. In John J. Kornacki, ed., Leading Congress: New Styles, New Strategies. Washington, DC: CQ Press.

Ripley, Randall B. 1969. Majority Party Leadership in Congress. Boston: Little, Brown.

Schlesinger, Joseph A. 1984. On the Theory of Party Organization. Journal of Politics 46:369-400.

1985. The New American Political Party. American Political Science Review 79:1152-1169.

Sinclair, Barbara. 1983. Majority Leadership in the U.S. House. Baltimore: The Johns Hopkins University Press.

. 1990. Congressional Leadership: A Review Essay and Research Agenda. In John J. Kornacki, ed., Leading Congress: New Styles, New Strategies. Washington, DC: CQ Press.

Stonecash, Jeffery M. 1988. Working at the Margins: Campaign Finance and Party Strategy in New York Assembly Elections. Legislative Studies Quarterly 12:495-514. 